\title{
PROTOCOLOS DE EXTRAÇÃO DE RNA E ATIVIDADE ENZIMÁTICA EM SEMENTES DE PIMENTA (Capsicum chinense)
}

Heloisa Oliveira dos Santos ${ }^{1}$, Elise de Matos Pereira ${ }^{2}$, Raquel Maria de Oliveira Pires ${ }^{1}$, Rucyan Walace Pereira ${ }^{1}$, Édila Vilela de Resende Von Pinho ${ }^{1}$

${ }^{1}$ Universidade Federal de Lavras - UFLA, E-mails: heloisa.ufs@gmail.com, raquel.mopires@gmail.com, rucyan.wp@gmail.com, edila@dag.ufla.br

${ }^{2}$ Universidade Estadual Paulista "Júlio de Mesquita Filho" - UNESP, E-mail: elizematosp@gmail.com

\section{RESUMO}

Nesse trabalho foram testados quatro métodos de extração de RNA (Método CTAB, Borato quente, Pure Link Reagent e Trizol Reagent), em quatro diferentes estádios de desenvolvimento de sementes de pimenta habanero (Capsicum chinense), com o objetivo de determinar qual método é mais eficiente na obtenção de um RNA de maior qualidade e quantidade. Além da extração do RNA, as sementes também foram submetidas às análises das isoenzimas esterase, superoxido dismutase, $\alpha$-amilase, $\beta$-amilase e endo- $\beta$-mananase. O método Pure Link Reagent, foi o que apresentou RNAs mais puros e sem degradação nas sementes de pimenta nos estádios de desenvolvimento testados, que poderão ser utilizados para a análise de expressão gênica.

Palavras-chave: Biotecnologia, Marcadores moleculares, Qualidade fisiológica

\section{RNA EXTRACTION PROTOCOLS AND ENZIMATIC ACTIVITY IN PEPPER SEEDS (Capsicum chinense)}

\section{ABSTRACT}

In this work were tested four methods of ARN extraction (method CTAB, CTAB, hot borate, Pure Link Reagent and Trizol Reagent), in four different development stages of habanero pepper seeds (Capsicum chinense), with the objective to determine which method is more efficient to obtain higher quality and quantity of ARN. Beyond the ARN extraction, seeds were also submitted to enzymatic analysis of esterase, superoxide dismutase, $\alpha$-amylase, $\beta$-amylase and endo- $\beta$-mannanase. The Pure Link Reagent method was the one, which presented the purest and without degradation RNAs in pepper seeds in the development stages tested, which may be used for the analysis of gene expression.

Keywords: Biotechnology, Molecular markers, Physiological quality 


\section{INTRODUÇÃO}

A pesquisa na área de biologia molecular, associada ao controle de qualidade de sementes, tem evoluído rapidamente e novas técnicas têm-se mostrado úteis na obtenção de classes distintas de marcadores moleculares. Estes auxiliam na elucidação dos fatores que afetam a qualidade, a manipulação, a identificação e a preservação do material genético, permitindo o monitoramento de todo o processo produtivo (DANTAS et al., 2002).

Segundo Carvalho et al. (2000), várias pesquisas têm sido desenvolvidas para detectar as diversas reações metabólicas que envolvem síntese e degradação de moléculas durante o desenvolvimento, a germinação e a deterioração de sementes.

A eletroforese, através da detecção de alterações na composição protéica e de enzimas específicas pode ser eficiente ferramenta para o acompanhamento da qualidade das sementes, uma vez que as sementes constituem excelente material para análise do polimorfismo isoenzimático. São relativamente fáceis de armazenar, frequentemente ricas em proteínas e enzimas de elevada atividade e, geralmente, livres de metabólitos secundários (fenóis, taninos, etc), que interferem na resolução e atividade enzimáticas (CHELIAK \& PITEL, 1984).
Dentro desta idéia a técnica da eletroforese de isoenzimas, possibilita a detecção dos estádios iniciais da deterioração, através da atividade de enzimas associadas com a degradação e oxidação de substâncias de reserva bem como biosíntese de novas substâncias. Priestley (1986) associou a perda de algumas formas de isoenzimas, tais como a peroxidase, fosfatase ácida, esterase e aminopeptidase, com o envelhecimento severo de um grupo de espécie de sementes.

Para a aplicação dessa técnica em seus diversos usos, é necessário realizar a otimização da sua metodologia para a espécie que se pretende estudar, definindo o tecido vegetal a ser macerado para obtenção das enzimas, o tampão de extração ideal para preservar as propriedades das enzimas extraídas, o sistema-tampão gel/eletrodo, o substrato e os sistemas enzimáticos. A adequação de todas estas variáveis metodológicas é responsável por se conseguir uma perfeita corrida eletroforética envolvendo boa migração das enzimas através da matriz, atividade e resolução de bandas satisfatórias para a análise dos zimogramas.

A técnica da transcrição reversa acoplada à reação de polimerase em cadeia, comumente chamada de RT-PCR ("Reverse Transcriptase-Polimerase Chain Reaction") 
já vem sendo utilizada para a diferenciação da expressão de genes de interesse a exemplo dos genes ligados ao desenvolvimento e formação de sementes (CADMAN et al., 2006; LEFEBVRE et al., 2006). No entanto, para que se obtenham resultados satisfatórios na utilização destas técnicas, faz-se necessário a obtenção de um RNA de boa qualidade e em quantidades adequadas.

$\mathrm{O}$ isolamento de RNA total de qualidade é um pré-requisito para estudos de expressão gênica incluindo transcriptase reversa (RT), PCR quantitativo em tempo real (RT-qPCR), construção de bibliotecas de cDNA ou análises de microarray (Cardillo et al., 2006). A principal dificuldade na extração de RNA é a presença de grande quantidade de ribonucleases (RNAses) estáveis e ativas nos tecidos, que permitem que o RNA (altamente instável) seja rapidamente degradado. Desta maneira, a primeira etapa em todos os métodos de isolamento de RNA após a pulverização dos tecidos, é a exposição deste material a tampões de extração. Estes apresentam substâncias como o cloreto de lítio que auxilia a precipitação do RNA e tiocianatoe guanidina que permite a manutenção do RNA intacto nas etapas posteriores da extração, através da degradação das ribonucleases endógenas (SAMBROOK \& RUSSEL, 2001).
Diversos métodos foram descritos e aplicados para extração de RNA total, baseados na utilização de agentes desnaturantes, tais como fenol e sais de guanidina. A principal preocupação na extração de RNA consiste na sua degradação por ribonucleases (RNAses), que são enzimas resistentes a tratamentos, inclusive térmicos (autoclavagem). A utilização de agentes desnaturantes permite a lise das células e a inativação das ribonucleases. $\mathrm{O}$ método básico emprega a extração com fenol seguida da precipitação do RNA por etanol. De forma a diminuir a contaminação com RNAses das soluções, equipamentos, vidrarias e reagentes é recomendável tratá-los com autoclavagem e/ou com DEPC (dietilpirocarbonato), agente inibidor de RNAses (GEUNA et al., 1998).

Para trabalhos que utilizam diferentes tecidos e/ou estádios de desenvolvimento é de extrema importância um método de extração eficiente para todos, independente da composição do material, a fim de minimizar as variações que possam existir quando utilizados diferentes protocolos (JAAKOLA et al., 2010).

As sementes, por possuírem altos níveis de compostos fenólicos, polissacarídeos e elevados níveis de RNAses (JAAKOLA et al., 2001), dificultam o processo de extração. Esses polissacarídeos 
formam uma estrutura gelatinosa que precipita durante a extração, afetando tanto a quantidade quanto a qualidade do RNA (SHARMA et al., 2003). No entanto, a depender do estádio de desenvolvimento desta semente, tais componentes podem variar o que poderá afetar a extração de RNA em alguns estádios e em outros não.

Após a extração faz-se necessária a avaliação da pureza e a quantificação do RNA, onde são observados os valores de absorbância a $280 \mathrm{~nm}, 260 \mathrm{~nm}$ e $230 \mathrm{~nm}$. A quantificação do RNA nas amostras extraídas é importante, uma vez que é aconselhável a utilização de aproximadamente as mesmas quantidades de RNA quando se comparam diferentes amostras (BUSTIN et al., 2009).

A relação entre a absorbância A260/A230 indica a contaminação por polissacarídeos ou polifenóis, e o valor da relação A260/A280 indica a contaminação por proteínas (MANNING, 1991). Segundo Asif et al. (2006) quando esses valores estiverem entre 1,8-2,1, respectivamente, indicam a descontaminação das amostras. Ressalta-se ainda que a relação de absorbância A260/A280 não indica diretamente a pureza do RNA, pois a presença de DNA ou resíduos de fenol altera esta relação (BUSTIN et al., 2009).
Existem vários procedimentos de quantificação de RNA, incluindo espectrofotometria, análise de microfluídos, eletroforese capilar, ou detecção de corante fluorescente. No entanto, os métodos produzem resultados diferentes, tornando-se desaconselhável a comparação dos dados obtidos com os diferentes métodos (BUSTIN, 2005).

Ao invés da comparação de métodos de quantificação aconselha-se a utilização de eletrofose em gel para determinar a integridade do RNA extraído, no entanto ressalta-se que o RNA observado será o ribossômico e nem sempre a integridade deste é suficiente para determinar um resultado satisfatório dependendo da técnica utilizada, a exemplo da RT-qPCR (BUSTIN et al., 2009).

Devido a presença de metabólitos secundários, polissacarídeos e polifenóis, a extração de RNA de qualidade em tecidos de sementes torna-se uma etapa de difícil padronização entre tecidos com diferentes teores de água e a obtenção de alta quantidade de RNA pode ser complicada pela suscetibilidade do RNA à degradação por RNAses. Visando a obtenção de um protocolo ideal para extração de RNA de qualidade para tecidos com diferentes teores de água de sementes de pimenta, objetivou-se 
com este trabalho identificar a metodologia mais adequada para isolar amostras de RNA em sementes colhidas aos 14, 45 e 70 dias após a antese, além de sementes secadas (8\%UR), que possam ser utilizadas em estudos moleculares sensíveis.

\section{MATERIAL E MÉTODOS}

\section{Extração de RNA}

Para a extração do RNA total em cada estádio de desenvolvimento, as sementes foram maceradas em nitrogênio líquido usando cadinho e pistilo. Estas foram submetidas a quatro diferentes métodos de extração de RNA: Purelink plant RNA (Invitrogen) e TRIzol $^{\circledR} \quad$ (Invitrogen) realizados de acordo com especificações dos fabricantes; Borato quente e CTAB (microextração) através de protocolos adaptados por Birtic \& Kranner, (2006) e Chang et al. (1993), respectivamente. Todos os materiais utilizados para extração foram tratados com solução diethilpirocarbonato (DEPC) a 0,1\% para inativar RNAses. As soluções utilizadas foram preparadas com água destilada autoclavada RNAse-free.

\section{Purelink plant RNA (Invitrogen)}

Para 0,2 g de tecido da semente, colocado em um microtubo de 2,0 ml, foram adicionados $500 \mu \mathrm{L}$ de PureLink Plant RNA e agitado em vórtex por 20seg. e mantido em repouso na posição horizontal por 5 min., para melhor homogeinização do material. Em seguida o material foi centrifugado a 14.000 xga $4^{\circ} \mathrm{C}$ durante $15 \mathrm{~min}$. Após a centrifugação o sobrenadante foi transferido para novo microtubo adicionando-se $300 \mu \mathrm{L}$ de clorofórmio, $100 \mu \mathrm{L}$ de cloreto de potássio (5M) seguido de agitação. Novamente foi realizada a centrifugação a14.000 xg a $4{ }^{\circ} \mathrm{C}$ durante 10 min. $O$ sobrenadante foi transferido para novo microtubo adicionando-se o mesmo volume de álcool isopropílico e o microtubo foi mantido em repouso durante $10 \mathrm{~min}$. Posteriormente o material foi centrifugado a $14.000 \mathrm{xg}$ a $4{ }^{\circ} \mathrm{C}$ por $10 \mathrm{~min}$. Em seguida foi descartado o sobrenadante e adicionou-se $1 \mathrm{ml}$ de etanol $70 \%$ centrifugando a $14.000 \mathrm{xg}$ em temperatura ambiente durante $1 \mathrm{~min}$. $\mathrm{O}$ sobrenadante foi removido e o pellet secado por $10 \mathrm{~min}$, o qual foi ressuspendido em 20 $\mu \mathrm{L}$ de água com DEPC $0,1 \%$ e armazenado a $-80^{\circ} \mathrm{C}$.

\section{TRIzol $^{\circledR}$ (Invitrogen)}

Foram utilizadas $0,2 \mathrm{~g}$ de tecido da semente, colocado em um microtubo de 1,5 $\mathrm{ml}$, foram adicionados $1 \mathrm{~mL}$ de TRIzol e agitado em vórtex por $30 \mathrm{seg}$ e mantido em repouso na posição horizontal por $5 \mathrm{~min}$, para 
melhor homogeinização do material. Em seguida o material foi centrifugado a 14.000 xga $4^{\circ} \mathrm{C}$ durante 15 min. Após a centrifugação a fase aquosa foi transferida para novo microtubo adicionando-se $200 \mu \mathrm{L}$ de clorofórmio seguido de agitação intensa por 15 seg e mantido em repouso na posição horizontal por $5 \mathrm{~min}$, para melhor homogeinização do material. Novamente foi realizada a centrifugação a 14.000 xg a $4{ }^{\circ} \mathrm{C}$ durante 15 min. Após centrifugação a mistura se separa em três fases: inferior orgânica, avermelhada contendo fenol, interfase e a superior aquosa e mais clara que foi transferida para um novo microtubo onde foram acrescidos $500 \mu \mathrm{L}$ de isopropanol para precipitação do RNA. Novamente foi realizada a centrifugação a14.000 xg a $4{ }^{\circ} \mathrm{C}$ durante $10 \mathrm{~min}$. Em seguida foi descartado o sobrenadante e adicionou-se $1 \mathrm{ml}$ de etanol $75 \%$ centrifugando a 14.000 xg em temperatura ambiente durante $1 \mathrm{~min}$. $\mathrm{O}$ sobrenadante foi removido e o pellet secado a $37^{\circ} \mathrm{C}$ por $10 \mathrm{~min}$, e ressuspendido em $30 \mu \mathrm{L}$ de água com DEPC 0,1\% e armazenado a $80^{\circ} \mathrm{C}$.

\section{Borato quente}

Inicialmente foi feito o preparo dos microtubos $(2,0 \mathrm{~mL})$ contendo $0,06 \mathrm{~g}$ de polivilpirrolidona (PVP) e $4 \mu \mathrm{L} \quad \mathrm{de}$
Dithiothreitol (DTT) 1,0M e adicionado $1 \mathrm{~mL}$ da solução tampão de extração (EGTA 30mM; Borax 0,2M; SDS 1\%; deoxicolato de sódio 1\%, pH 9,0), agitado em vórtex por 30 seg. e aquecido a $80^{\circ} \mathrm{C}$. Em seguida, foram adicionados a cada microtubo $0,2 \mathrm{~g}$ de tecido da semente, $0,001 \mathrm{~g}$ de proteinase $\mathrm{K}$ e agitado em vórtex por 30 seg. e incubado a $42^{\circ} \mathrm{C}$ por $1,5 \mathrm{~h}$. Após o repouso foi adicionado $80 \mu \mathrm{L}$ de $\mathrm{KCl}(2,0 \mathrm{M})$ a cada tubo e incubado em gelo por 45 min. Em seguida o material foi centrifugado a 14.000 xga $4^{\circ} \mathrm{C}$ durante 20 min. A fase aquosa (inferior) foi transferida para novo tubo $(1,5 \mathrm{~mL})$, adicionado $300 \mu \mathrm{L}$ de cloreto de lítio 8,0 M e incubado por $2 \mathrm{~h}$ a $-20^{\circ} \mathrm{C}$. Novamente foi realizada a centrifugação a 14.000 xg a $4{ }^{\circ} \mathrm{C}$ durante 20 min. Em seguida foi descartado $o$ sobrenadante e adicionou-se $750 \mu \mathrm{L}$ de cloreto de lítio 2,0M centrifugando a 14.000 $\mathrm{xg}$ a $4{ }^{\circ} \mathrm{C}$ durante $10 \mathrm{~min}$. Em seguida foi descartado o sobrenadante e adicionou-se $400 \mu \mathrm{L}$ de etanol $70 \%$ centrifugando a 14.000 xg a $4{ }^{\circ} \mathrm{C}$ durante $10 \mathrm{~min}$. O sobrenadante foi removido e o pellet secado por $10 \mathrm{~min}$, o qual foi ressuspendido em $20 \mu \mathrm{L}$ de água com DEPC $0,1 \%$ e armazenado a $-80^{\circ} \mathrm{C}$.

\section{$C T A B$}

Foram utilizados $0,2 \mathrm{~g}$ de tecido da semente, colocado em um microtubo de 2,0 
$\mathrm{mL}$, foram adicionados $700 \mu \mathrm{L}$ da solução tampão de extração (CTAB 2\%; $\mathrm{NaCl}$ 2,0M; EDTA 25mM; Tris HCl 100mM; PVP 2\%; $\beta$ mercaptoetanol $2 \%$ ) e agitado levemente e incubado a $65^{\circ} \mathrm{C}$ por $20 \mathrm{~min}$. Após incubação foi acrescentado $800 \mu \mathrm{L}$ de clorofórmio e agitado levemente e em seguida centrifugado a $14.000 \mathrm{xg}$ a $4{ }^{\circ} \mathrm{C}$ durante $10 \mathrm{~min}$. $\mathrm{O}$ sobrenadante foi transferido para novo microtubo $(2,0 \mathrm{~mL})$ e acrescido de $600 \mu \mathrm{L}$ de clorofórmio e novamente centrifugado a $14.000 \mathrm{xg}$ a $4{ }^{\circ} \mathrm{C}$ durante $10 \mathrm{~min}$. $\mathrm{O}$ sobrenadante foi transferido para novo microtubo de 1,5 mL e adicionado cloreto de lítio $12,0 \mathrm{M}$ para concentração final de $2,5 \mathrm{M} \mathrm{e}$ incubado por 24 horas a $5^{\circ} \mathrm{C}$ para precipitação do RNA. Novamente foi realizada a centrifugação a14.000 xg a $4{ }^{\circ} \mathrm{C}$ durante 30 min. O sobrenadante foi descartado e em seguida foi adicionado $1 \mathrm{~mL}$ de cloreto de lítio 2,5M. Novamente foi realizada a centrifugação a14.000 xg a $4{ }^{\circ} \mathrm{C}$ durante 15 min. O sobrenadante mais uma vez foi descartado e em seguida foi adicionado $1 \mathrm{~mL}$ de etanol $70 \%$ e novamente centrifugado a $14.000 \mathrm{xg}$ a $4{ }^{\circ} \mathrm{C}$ durante $10 \mathrm{~min}$. O sobrenadante foi removido e o pellet secado por $10 \mathrm{~min}$, o qual foi ressuspendido em 20 $\mu \mathrm{L}$ de água com DEPC $0,1 \%$ e armazenado a $-80^{\circ} \mathrm{C}$.
A quantificação do RNA total extraído foi feita no equipamento Nanovue Plus medindo-se a absorbância a 260 e 280nm, observando a razão de comprimento de onda 260/280 nm e 260/230 nm.

A integridade do RNA também foi analisada por eletroforese em gel de agarose $(1,5 \%)$ contendo tampão TBE $1 \mathrm{x}$ e corado com solução de brometo de etídio. A corrida aconteceu a 90V durante $30 \mathrm{~min}$.

\section{Sistemas enzimáticos}

EST, SOD, $\alpha$-AMI e $\beta$-AMI.

Para análise eletroforética de enzimas as sementes, nos quatro estádios de desenvolvimento, foram trituradas na presença de PVP e nitrogênio líquido em mortar sobre gelo e posteriormente armazenadas à temperatura de $-86^{\circ} \mathrm{C}$.

Sub amostras de 100mg do material macerado, foram acrescidas $250 \mu 1$ do tampão de extração (Tris $\mathrm{HCl}$ 0,2M pH 8,0) e 0,1\% de $\beta$-mercaptoetanol. O material foi colocado em geladeira over night e depois centrifugado a $14000 \mathrm{rpm}$ por 30 minutos a $4^{\circ} \mathrm{C}$. A eletroforese em géis de poliacrilamida foi desenvolvida em sistema descontinuo $(7,5 \%$ gel de separação e 4,5\% gel de concentração). O sistema tampão gel/eletrodo utilizado foi o Tris-glicina pH8.9. Para proceder a corrida eletroforética, foram aplicados na canaleta do 
gel $50 \mu \mathrm{L}$ do sobrenadante e a corrida realizada a $4^{\circ} \mathrm{C}$, a $120 \mathrm{~V}$, por 5 horas. Ao término da corrida, os géis foram revelados para as enzimas esterase, superóxido dismutase, alfa amilase e beta amilase, conforme Alfenas et al. (2006).

\section{Endo- $\beta$-mananase}

Para a extração da enzima endo- $\beta$ mananase, em cada microtubo com100mg de pó de cada amostra, foram adicionados $300 \mu \mathrm{l}$ do tampão de extração contendo 0,1 M Hepes e 0,5 $\mathrm{M}$ de $\mathrm{NaCl}(\mathrm{pH}$ 8,0) mais ácido ascórbico na proporção de $5 \mathrm{mg}$ do ácido para cada $\mathrm{ml}$ de tampão, em três repetições. Em seguida, os microtubos contendo as amostras foram agitados em Vortex por 1 minuto e levados para centrífuga a 10.000 g por 30 minutos a $4^{\circ} \mathrm{C}$. O sobrenadante foi aplicado em gel montadocom $6 \mathrm{ml}$ de LBG (Locust BeanGum-Sigma nr 0753), 0,24 g de agarose (Qbiogene) e $24 \mathrm{ml}$ de tampão pH 5,0. O LBG 0,5\% foi preparado aquecendo a solução por 2 horas a $80^{\circ} \mathrm{C}$, seguido de resfriamento em temperatura ambiente.

Já o tampão pH 5,0 foi preparado adicionando-se $11 \mathrm{ml}$ de ácido cítrico1M, 50 $\mathrm{ml}$ de Na2HPO4 e $149 \mathrm{ml}$ de água destilada, num total de $210 \mathrm{ml}$. Os suportes do gel com U-frame (Pharmacia 8001106-89) (vidros) foram limpos com etanol. Este suporte foi coberto com Gelbond film (Pharmacia nr 80112932), ficando o lado hidrofóbico em contato com o primeiro vidro, para que o lado hidrofílico ficasse em contado com o gel. O gelbond foi coberto com o segundo suporte e estes suportes foram unidos por prendedores. O gel antes de ser aplicado, foi aquecido em microondas por 1 minuto até a total dissolução da agarose. Pelo mesmo período, o suporte foi aquecido em estufa a $80^{\circ} \mathrm{C}$ para que não houvesse perigo de trincas no vidro por diferenças de temperatura entre o vidro e o gel. Neste momento foi feita a aplicação em temperatura ambiente. Após a solidificação, o gel foi armazenado em geladeira por um período de $24 \mathrm{~h}$. O gel foi furado com furador de $2 \mathrm{~mm}$ de diâmetro e estes furos foram succionados para retirada de restos de gel com bomba a vácuo. Foram aplicados $2 \mu l$ do extrato da amostra por furo, em 3 repetições de cada amostra. $\mathrm{O}$ gel foi transferido para um germinador a $25^{\circ} \mathrm{C}$ por período de 21 horas, no escuro, em câmara úmida.

Para a revelação, o gel foi inicialmente lavado em água destilada, lavado em tampão (tampão do gel) por 30 min e novamente lavado em água destilada. Logo após, o gel foi coberto com o corante vermelho congo a $0,5 \%$ por $30 \mathrm{~min}$ e colocado em etanol por 10 min para a remoção do corante. Removido o etanol com 
água destilada, foi adicionada uma solução de $1 \mathrm{M}$ de $\mathrm{NaCl}$ até a observação visual da formação de halos brancos nos furos que continham as amostras. Nesse momento, foi feita a medição do diâmetro dos halos em duas direções com um paquímetro resultando em uma média.

Para o cálculo da atividade da enzima, foi feita uma comparação com a curva padrão gerada pela endo- $\beta$-mananase comercial de Aspergillus niger (Megazyme). O cálculo da atividade da enzima endo- $\beta$-mananase foi realizado segundo Downie (1994).

\section{RESULTADOS E DISCUSSÃO}

Para os procedimentos de extração, o mesmo material coletado foi utilizado e a mesma quantidade de tecido foi padronizada. Ressalta-se que foram testadas duas quantidades de material $(0,1$ e $0,2 \mathrm{~g})$, e quando da utilização de $0,2 \mathrm{~g}$ de tecido vegetal pulverizado por amostra obteve-se maiores quantidades em espectrofotometria e melhor visualização do RNA em gel de agarose.

Os métodos que apresentaram quantidade de RNA suficiente para posteriores trabalhos foram Purelink plantRNA e TRIzol, no entanto, os métodos de extração com borato quente e CTAB podem ser utilizados desde que sejam adequados alguns parâmetros para a espécie em estudo.

As relações de pureza e as concentrações dos RNAs provenientes de todos os métodos de extração avaliados foram registradas (Tabela 1). Para a avaliação da pureza, são observados os valores de absorbância a $280 \mathrm{~nm}, 260 \mathrm{~nm}$ e $230 \mathrm{~nm}$. Ressalta-se ainda que a relação entre a absorbância A260/A230 indica a contaminação por polissacarídeos ou polifenóis, e o valor da relação A260/A280, indica a contaminação por proteínas.

Quando esses valores estiverem entre 1,8-2,1, respectivamente, indicam a descontaminação das amostras (ASIF et al. 2006).

Ao comparar os métodos descritos no trabalho, pode-se observar que o método do Trizol e o Pure link apresentaram maior qualidade das amostras. Em destaque ao método do purê link, que, como pode ser observado (Tabela 1) apresentou para todos os estádios de desenvolvimento de sementes os melhores resultados, com as relações de absorbância ideais, determinando amostras com pouca ou nenhuma contaminação com proteínas e polissacarídeos. Isso pode estar relacionado ao uso de substâncias como o PVP e $\beta$-mercaptoetanol, que possuem a função de reduzir as substâncias oxidantes e 
os compostos fenólicos (JAAKOLA et al., 2001).

Os métodos do Borato quente, CTAB e principalmente o Trizol, apresentaram amostras contaminadas com proteínas e polifenóis, segundo a relação dos valores de absorbância, que representaram valores menores aos recomendados (Tabela 1).

$\mathrm{Na}$ extração realizada utilizando o Trizol com o protocolo sugerido pelo fabricante, é observado um baixo rendimento entre os materiais nos diferentes estádios de desenvolvimento e consequentemente uma alta contaminação, podendo ser resultante da presença de proteínas e compostos polifenolicos. Resultado semelhante foi observado em frutos de Vaccinium myrtillus por Jaakola et al. (2001). Ressalta-se ainda que esse reagente é composto da substância química fenol, que pode também causar danos a cauda poli-A do mRNA extraído (AZEVEDO et al., 2003), dificultando a síntese do cDNA e análises posteriores.

Quando da análise dos estádios de desenvolvimento das sementes separadamente (Tabela 1), pode-se observar que o tecido que possui maior qualidade em todos os métodos foi aos 14 dias após a antese, caracterizado pela presença de poucos polifenóis. A partir desse ponto é possível que se tenha um maior acúmulo de compostos fenólicos, polissacarídeos e elevados níveis de RNAses (JAAKOLA et al., 2001), dificultando assim o processo de extração.

Tabela 1. Comparação das médias da qualidade dos RNAs isolados de diferentes estádios de desenvolvimento de sementes de pimenta habanero. Lavras, MG, Fevereiro de 2015.

\begin{tabular}{lccc|ccc}
\hline \multirow{2}{*}{$\begin{array}{c}\text { Estádios de } \\
\text { desenvolvimento }\end{array}$} & $\begin{array}{c}\text { Quantidade } \\
\text { de RNA } \\
(\mathrm{ng} / \mu \mathrm{L})\end{array}$ & $\begin{array}{c}\text { Pureza } \\
\mathrm{A}_{260} / \mathrm{A}_{280}\end{array}$ & $\begin{array}{c}\text { Pureza } \\
\mathrm{A}_{260} / \mathrm{A}_{230}\end{array}$ & $\begin{array}{c}\text { Quantidade } \\
\text { de RNA } \\
(\mathrm{ng} / \mu \mathrm{L})\end{array}$ & $\begin{array}{c}\text { Pureza } \\
\mathrm{A}_{260} / \mathrm{A}_{280}\end{array}$ & $\begin{array}{c}\text { Pureza } \\
\mathrm{A}_{260} / \mathrm{A}_{230}\end{array}$ \\
\hline 14 DAA & 318 & 2.1 & 1.47 & 520 & 2.2 & 0.8 \\
45 DAA & 203 & 2.0 & 1.6 & 411 & 2.0 & 0.7 \\
70 DAA & 103 & 2.2 & 1.57 & 303 & 1.9 & 1.3 \\
Semente seca & 101 & 1.9 & 1.46 & 317 & 1.7 & 1.4 \\
\hline
\end{tabular}

\begin{tabular}{lccc|ccc}
\hline \multirow{2}{*}{$\begin{array}{c}\text { Estádios de } \\
\text { desenvolvimento }\end{array}$} & $\begin{array}{c}\text { Quantidade } \\
\text { de RNA } \\
(\mathrm{ng} / \mu \mathrm{L})\end{array}$ & $\begin{array}{c}\text { Pureza } \\
\mathrm{A}_{260} / \mathrm{A}_{280}\end{array}$ & $\begin{array}{c}\text { Pureza } \\
\mathrm{A}_{260} / \mathrm{A}_{230}\end{array}$ & $\begin{array}{c}\text { Quantidade } \\
\text { de RNA } \\
(\mathrm{ng} / \mu \mathrm{L})\end{array}$ & $\begin{array}{c}\text { Pureza } \\
\mathrm{A}_{260} / \mathrm{A}_{280}\end{array}$ & $\begin{array}{c}\text { Pureza } \\
\mathrm{A}_{260} / \mathrm{A}_{230}\end{array}$ \\
\hline 14 DAA & 873 & 1.9 & 0.6 & 2480 & 2.0 & 1.8 \\
45 DAA & 627 & 1.9 & 0.8 & 1956 & 2.0 & 1.9 \\
70 DAA & 542 & 1.7 & 0.6 & 1994 & 1.6 & 1.9 \\
Semente seca & 436 & 1.8 & 0.5 & 1498 & 1.8 & 1.7 \\
\hline
\end{tabular}


Segundo Sharma et al. (2003), esses polissacarídeos formam uma estrutura gelatinosa que precipita durante a extração, afetando não só a quantidade quanto na qualidade do RNA obtido.

Em relação à integridade das amostras, pode ser observada (Figura 1), uma relação entre a integridade e a qualidade, determinando que nos métodos que apresentaram qualidade satisfatória, mostraram também integridade das bandas $28 \mathrm{~S}$ e $18 \mathrm{~S}$ característica do rRNA.

Pela análise de variância (Tabela 2), pode-se verificar diferenças significativas na qualidade fisiológica das sementes de pimenta habanero nos diferentes estádios de desenvolvimento.

Pode-se verificar também diferenças nos teores de água das sementes nos diferentes estádios. Vale ressaltar que as sementes não foram secadas antes da extração das enzimas.

Observa-se, pela análise dos padrões enzimáticos, que as enzimas esterase (EST), $\alpha$-amilase, $\beta$-amilase e superóxido dismutase (SOD) apresentaram bons padrões de banda (Figura 2). A esterase é uma enzima que pode estar envolvida no desdobramento de lipídeos durante o processo de germinação e também pode atuar sobre fosfolipídeos de membrana, provocando a peroxidação de lipídeos. A atividade dessa enzima está muito ligada à composição química das sementes. Alto teor de gordura das sementes favorece a liberação de ácido graxos dos lipídeos, os quais são usados na beta oxidação, como fonte de energia para os eventos germinativos.

A superóxido dismutase exerce um importante papel em proteger a célula contra os efeitos deletérios de radicais superóxidos livres. Goel et al. (2003) verificaram que a perda da viabilidade de sementes de algodão está associada ao decréscimo da atividade da superóxido dismutase. Logo, o aumento na qualidade das sementes de pimenta, como observado na (Tabela 2), pode estar diretamente ligado ao aumento da atividade da SOD, durante os estádios de desenvolvimento da semente.

Houve aumento na atividade da enzima $\alpha$-amilase com o avanço no estádio de maturação. No entanto, quando da atividade da $\beta$ - amilase, o padrão observado foi o inverso. Ressalta-se ainda que em sementes secas foi possível observar a menor atividade da $\alpha$-amilase.

De acordo com Nedel et al. (1996), dentro de um grupo de enzimas, a $\alpha \mathrm{e} \beta$ amilases estão envolvidas no principal sistema de degradação do amido. O desenvolvimento da atividade da amilase constitui um importante evento, podendo ser 
detectado durante o início da germinação das sementes, sendo seu principal papel, plântula até que ela se torne fotossinteticamente auto-suficiente. disponibilizar substratos para utilização da
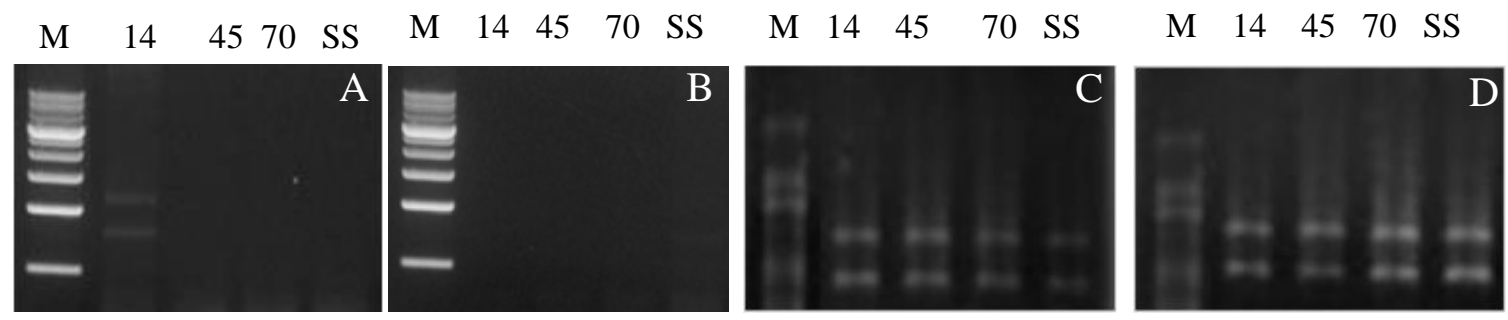

Figura 1. Gel de agarose $1,5 \%$ corado com brometo de etídio. A- Borato quente; B - CTAB; C Trizol; D - Pure link. Lavras, MG, Fevereiro de 2015.

Tabela 2. Valores médios de plântulas normais, obtidos no teste de germinação (\%) e grau de umidade de sementes de pimenta malagueta e habanero colhidas em diferentes estádios de desenvolvimento. Lavras - MG, Fevereiro de 2015.

\begin{tabular}{ccc}
\hline Estádios & Germinação & U\% \\
\hline 14DAA & $11 \mathrm{~d}$ & 51 \\
45DAA & $25 \mathrm{c}$ & 43 \\
70DAA & $32 \mathrm{~b}$ & 31 \\
S. Seca & $98 \mathrm{a}$ & 9 \\
\hline CV $(\%)$ & 2,99 & -- \\
\hline
\end{tabular}
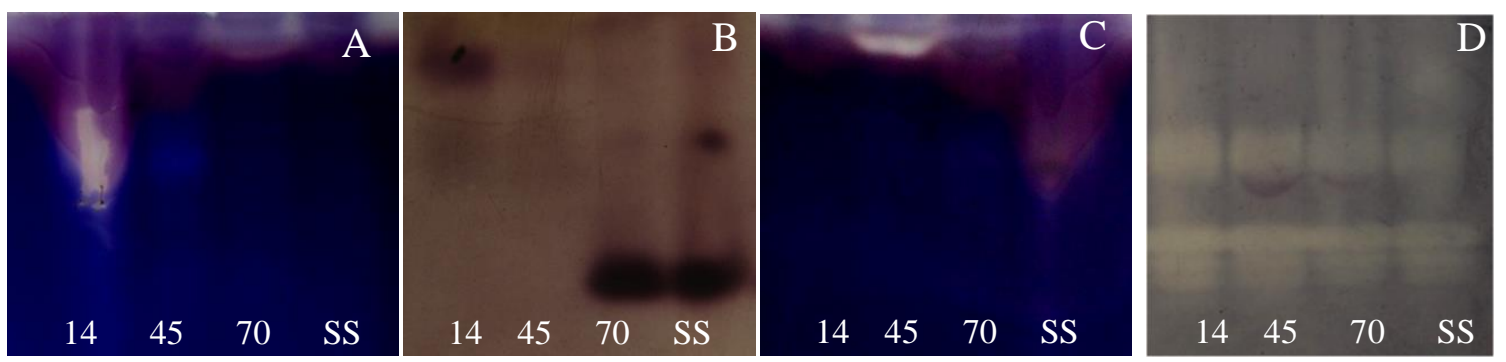

Figura 2. Padrões enzimáticos. A - Alfa amilase; B - Esterase; C - Beta amilase; D - Superóxido dismutase. Lavras - MG, Fevereiro de 2015. 
Um grande número de tipos de dormência de sementes decorre do bloqueio da ação da $\alpha$ - amilase. A ocorrência desta enzima é largamente distribuída nas plantas, principalmente associada com a $\beta$ - amilase. A $\alpha$-amilase presente nas sementes dormentes encontra-se em pequenas quantidades, mas durante a germinação todas as sementes rapidamente desenvolvem esta enzima. Desta maneira a $\alpha$-amilase pode ser prontamente encontrada nas sementes em germinação (MAYER, 1976).

Em relação à enzima endo- $\beta$ mananase houve aumento da atividade em sementes de pimenta habanero (Figura 3) nos estádios de desenvolvimento mais avançados. Foi observada, ainda, menor atividade da enzima nas sementes secas.

Isto se deve ao fato de a enzima endo$\beta$-mananase estar envolvida na degradação do endosperma na germinação das sementes. Em sementes de alface e café esta enzima é considerada chave no processo de germinação, estando envolvida na degradação de mananas no momento da germinação, resultando no enfraquecimento das paredes celulares do endosperma (SILVA et al., 2004; VEIGA,2007).

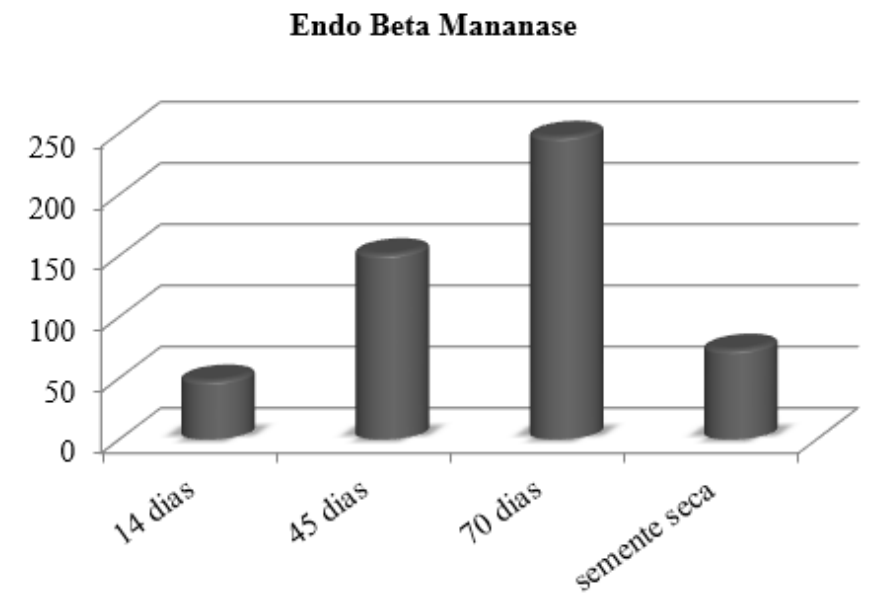

Figura 3. Atividade da enzima endo- $\beta$-mananase em sementes depimenta habanero em diferentes estádios dedesenvolvimento. Lavras - MG, Fevereiro de 2015.

\section{CONCLUSÕES}

A extração realizada com CTAB e Borato quente apresenta as amostras contaminadas, sendo considerados métodos ineficientes para obter RNA de sementes de pimenta de boa qualidade. A extração de RNA de sementes de pimenta utilizando o reagente Pure Link, independente do estádio de desenvolvimento, é eficiente e pode ser utilizado para obtenção de RNA de boa qualidade. Há variações na atividade das 
enzimas esterase, $\alpha$ e $\beta$-amilase, superóxido desmutase e endo- $\beta$-mananase durante o desenvolvimento das sementes de pimenta habanero.

\section{REFERÊNCIAS}

ASIF, M.; TRIVEDI, P.; SOLOMOS, T.; TUCKER, M. 2006. Isolation of highquality RNA from apple (Malus domestica) fruit. Journal of Agricultural and Food Chemistry, Washington, v.54, n. 15, p.5227-5229.

AZEVEDO, H.; LINO-NETO, T.; TAVARES, R.M. 2003. An improved method for high quality RNA isolation from needles of adult maritime pine trees. Plant Molecular Biology Reporter, Düsseldorf, v. 21, p. 333-338.

BIRTIC, S.; KRANNER, I. 2006. Isolation of high-quality from polyphenol-, polysaccharide and lipid-rich seeds. Phytochemical Analysis, Liverpool, v.17, p.144-148.

BUSTIN S. A. 2005. Real-time, fluorescencebased quantitative PCR: a snapshot of current procedures and preferences. Expert Review of Molecular Diagnostics, London, v.5, p. 493-498.

BUSTIN, S. A.; BEAULIEU, J. F.; HUGGETT, J.; JAGGI, R.; KIBENGE, F.S.; OLSVIK, P A. PENNING, L. C.; TOEGEL, S. 2009. MIQE précis: Practical implementation of minimum standard guidelines for fluorescence based quantitative real-time PCR experiments. Clinical Chemistry, London, v.55, p. 611-622.

CADMAN, C. S. C.; TOOROP, P. E.; HILHORST, H. W. M.; FINCHSAVAGE, W. E. 2006. Gene expression profiles of Arabidopsis Cvi seed during cycling through dormant and non-dormant states indicate a common underlying dormancy control mechanism. Plant Journal, Eastlansing, v. 46, p. 805-822.

CARDILLO, A. B.; GIULIETTI, A. M.; MARCONI, P. L. 2006. Analysis and sequencing of h6hmRNA, last enzyme in the tropane alkaloids pathway from anthers and hairy root cultures of Brugmansia candida (Solanaceae). Electronic Journal of Biotechnology, Valparaíso, v.9, p.196-198.

CARVALHO, M. L. M.; VIEIRA, M. G. G. C.; VON PINHO, E. R. 2000 Aplicação de técnicas moleculares no controle de qualidade de sementes. Biotecnologia Ciência \& Desenvolvimento, Brasília, v.3, p.44-47.

CHANG, S.; PURYEAR, J.; CAIRNEY, J. A 1993. Simple and efficient method for isolating RNA from pine trees. Plant Molecular Biology Reporter, Athens, v.11, p.113-116.

CHELIAK, W. M.; PITEL, J. A. 1984. Techniques for starch gel electrophoresis of enzymes from forest tree species. Information report PI-X, Ontario, v.42, p.1-13.

DANTAS, B.F.; ARAGÃO, C. A.; RAÚJOJÚNIOR, J. P.; RODRIGUES, J. D.; CAVARIAN, C.; NAKAGAWA, J. 2002. Padronização da metodologia do RT-PCR utilizado para identificação do mRNA da alfa-amilase em sementes de milho. Revista brasileira de sementes, Viçosa v. 24, p. 113-117.

GEUNA, F.; HARTINGS, H.; SCIENZA, A. 1998. A new method for rapid extraction of high quality RNAfrom recalcitrant tissues of grapevine. Plant Molecular Biology Reporter, Athens, v.16, p.61-67. GOEL, A.; GOEL, A. K.; SHEORAN, I. S. 2003. Changes in oxidative stress enzymes during artificial ageing in cotton (Gossypium hirsutum L.) seeds. Journal Plant Physiology, Toronto, v. 160, p. 1093-1100.

JAAKOLA L., SUOKASM.; HÄGGMANH. 2010. Novel approaches based on DNA 
barcoding and high-resolution melting of amplicons for authenticity analyses of berry species. Food Chemistry, Colney, v. 123, p. 494-500.

JAAKOLA, L.; PIRTTILA, A.M.; HALONEN, M.; HOHTOLA, A. 2001. Isolation of high quality RNAfrom bilberry (Vaccinium myrtillus L.) fruit. Molecular Biotechnology, New York, v.19, p.201-203.

LEFEBVRE, V.; NORTH, H.; FREY, A.; SOTTA, B.; SEO, M.; OKAMOTO, M.; NAMBARA, E.; MARION-POLL, A. 2006. Funtional analysis of Arabidopsis NCED6 and NCED9 genes indicates that ABA synthesized in the endosperm is involved in the induction of seed dormancy. Plant Journal, Eastlansing, v. 45, p. 309-319.

MAYER, A. M.; POLJAKOFF-MAYBER, A. 1989. The germination of seeds. 4. ed. Toronto: Pergamon Press. 270p.

NEDEL, J. L.; ASSIS, F. N.; CARMONA, P. S. 1996. A planta de arroz-morfologia e fisiologia. Pelotas: UFPEL, 1996. 56p.

PRIESTLEY, D. A. 1986 Seed aging. IthacaNY: Cornell University Press, . 304 p.

SAMBROOK, J.; RUSSEL., D. W. 2001. Molecular cloning - a laboratory manual. 3. ed. Cold Spring Harbor Laboratory Press: New York.

SHARMA, A. D.; GILL, P. K.; SINGH, P. 2003. RNA isolation from plant tissues rich in polysaccharides. Analytical Biochemistry, Bethesda, v.314, p.319321.

SILVA, E. A. A; TOOROP, P. E; AELST, A. C. V.; HILHORST, H. W. M. 2004. ABA regulates embryo growth potential and endosperm cap weakening during coffee (Coffea arabica cv. Rubi) seed germination. International Journal of Plant Biology, Pavia v.220, p.251-261.

VEIGA, A. D.; GUIMARÃES, R.M.; ROSA, S. D. V. F.; VON PINHO, E. V. R.; SILVA, L. H. C.; VEIGA, A. D. 2007. Armazenabilidade de sementes de cafeeiro em diferentes estádios de maturação e submetidas a diferentes métodos de secagem. Revista Brasileira de Sementes, Viçosa, v.29, p.83-91.

Recebido em: 7/10/2015 Aceito para publicação em: 14/10/2016 